\title{
Election Decision Support System Based on the Best Teacher Performance Assessment in State Smp 2 One Roof SAW Method Using STM Hilir
}

\author{
Tengku Afan Adhar ${ }^{1}$, Bosker Sinaga $^{2}$, Sulindawaty ${ }^{3}$ \\ ${ }^{1.2,3}$ Informatics Engineering Study Program, STMIK Pelita Nusantara Medan, J1. Iskandar \\ Muda 1 Medan, North Sumatra 20154, Indonesia \\ E-mail: tengkuafan02@gmail.com
}

\begin{abstract}
The process of teacher performance assessment Effectively, precisely, Objectively, and transparently is the important point in selecting the best teacher assessment based on their performance. This assessment was Carried out in SMP Negeri 2 One Roof STM Hilir to avoid the accusations of Injustice and family relationship with the assessor in the school, both the Headmaster and the teacher selection committee. Therefore, a decision system is needed in selecting the decision. One method is the which can be used in solving the problem of Multiple Criteria Decision Making (MADM) is by using Simple Additive weighting (SAW) method, Because The method concept is so easy to understand, simple, effective computationally and has ability in measuring the relative performance of alternative decisions in mathematical form. In addition, Also the design application used UML (Unified Modeling Language) is implemented a system roomates in the software by using Web Programming and MySQL as its database. Finally, based on the design of this application, it can be seen that the decision system by using SAW method is very effective, fast, computerized and transparent accurately in Determining the teacher performance in SMPN 2 One Roof STM Hilir.
\end{abstract}

Keywords: Decision System, Teacher Performance Assessment, Simple Additive weighting (SAW) Method, Unified Modeling Language (UML)

\section{Introduction}

Today many teachers either local unit level, the provincial level in the selection of the best teachers based on performance appraisal is not transparent, such young ages teachers and fewer working age gets good ratings because of the element of nepotism and kinship with the penilaan. There are also teachers who actually have work experience longer but not chosen to be the best teacher, Many people who pointed this injustice caused adannya collusion and nepotism factor circulating among the Department of Education both the principal and the best teacher of the election committee. This will not happen if the related offices and schools have been using an effective method of determining the best teacher,

This is similar to what happened at SMAN 15 Tangerang, where the Teacher Performance Assessment (PKG) is done now is done manually on the assessment sheet which is subjective, because there has been no effective assessment aspects of the Teacher Performance Assessment. (Source: Rohmat Taufik, Chandra Adi Saputra, SISFOKOM Journal Volume 07, Number 1, 2018)

The problem is the decision making process of finding the best options in determining the best teacher of all alternatives. Multiple criteria decision making is part of the decision-making is complex. Which in this case would be excluded from some people to make decisions by using a variety of criteria that have a certain weight value and should be considered in order to obtain the optimal solution of a problem. And one of the methods used in assessing the performance of the best teachers in SMPN 2 One Roof STM Hillir is Simple Additive weighting method (SAW).

\section{Theory}

Based Irwanto (2012: 35), the system can be defined as a set of components that interact in order to implement the model and functional transform given inputs into outputs for actors. And Murdick and Ross (2011: 56) also defines the system is a set of elements that are joined together for a common goal. Therefore it can be dsimpulkan that the system is a network that consists of components that are interconnected in order to accomplish a goal in specific activities. In this case the need to do a good cooperation so that the system can work as specified and produced a perfect target.

Decision support system is a concept of computer-based interactive system that can be used to support and assist in decision making structured and unstructured. Which in this case all activity must follow various stages, which starts from identifying the problem, choose the relevant data, determine the approach to evaluating alternative choice in the decision-making process. 


\subsection{Simple Additive weighting method (SAW)}

Simple Additive weighting method (SAW) is one method that can help to solve the problem of Multiple Attribute Decision Making (MADM). According to Dicky Nofriansyah (2014: 12), this method is known as a weighted summation method that has a basic concept, namely: to seek a weighted sum of rating performance on each alternative. In designing this method, the process of normalizing the decision matrix is also needed to scale with all the ratings of existing alternatives. There are several steps to resolve the Simple Additive weighting method (SAW), as follows:

a. Determine the criteria to be used as a reference in the decision.

b. Determine the suitability of alternative rating on each criterion.

c. Make decisions based on criteria matrix $(\mathrm{Ci})$ and normalized matrix

d. Obtain the final results of the ranking process is the summation of the normalized $\mathrm{R}$ matrix multiplication with the weight vector in order to obtain the greatest value is selected as the best alternative (Ai) as a solution.

$$
r_{i j}= \begin{cases}\frac{x_{i j}}{\operatorname{Max}_{i j}} & \text { jika jadalah atribut keuntungan (benefit) } \\ \frac{\operatorname{Min}_{i j}}{x_{i j}} & \text { jika jadalah atribut biaya (cost) }\end{cases}
$$

Where :

Rij $\quad=$ Normalized performance rating

Maxij = Maximum value of each row

and columns

Minij = Minimum value of each row

and columns

$\mathrm{Xij} \quad=$ Rows and columns of a matrix

With rij is the normalized performance rating of alternatives on attribute $\mathrm{Ai} \mathrm{Cj} ; \mathrm{i}=1,2, \ldots \mathrm{m}$ and $\mathrm{j}=1,2, \ldots$, n. Preference value for each alternative $(\mathrm{Vi})$ is given as:

Where :

$$
\mathrm{V}_{i}={ }_{j=1} w_{j} r_{i j}
$$

$\mathrm{Vi} \quad=$ The final value of the alternative

wj $\quad=$ The weights have been determined

rij $=$ Normalization matrix

Vi larger value indicates that the alternative is selected

\section{Analysis}

Step-by-step research methodology follows the determination of the object, the object of the research restriction, data collection, data analysis and conclusions. In this study, researchers used the approach to R \& D (Research and Development), namely:

a. to study literature

b. conduct interviews and debriefing in data collection by Drs, Suliano Best Teacher on the criteria and the procedures Assessment,

c. designing Design Systems are classified into sections UML Use Case Diagrams, Activity Diagrams and Class Diagrams and design of the application form,

d. implement the system in the form of software using Web programming language and MySQL as the database is.

\subsection{Data analysis} research

The data analysis consisted into three, namely, system requirements analysis, system analysis are built, and

Here is a flowchart of a system that is built: 


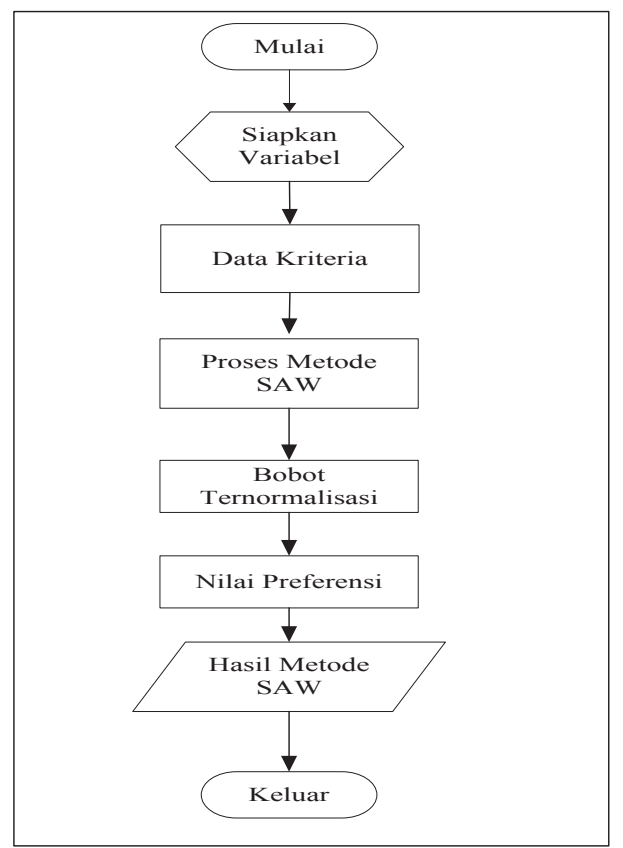

Fig 1. Flow chart Penilaan Teacher Performance

\subsection{Analysis Methods}

SAW method is selected because this method determines the weight values for each attribute, and then continued with the process of ranking which shall be to select the best alternative from a number of alternatives. Dalamhal this alternative question is yangmemiliki teacher Teacher Performance Assessment (PKG) is the highest based on the criteria that have been determined. With the method of ranking the diharapkanpenilaian would be more appropriate because it is based on the value of the criteria and weighting that have been specified. There are several stages in the calculation of SAW algorithm is as follows:

a. Determining factors and weighting factors where the total weighting must be equal to 1

b. Filling objectively value between 0-1 for each factor in the decision.

c. Calculating the weight evaluation of weight calculation between factorweight and evaluation factor and the sum of all the results of the evaluation to obtain a total weight of evaluation results.

The steps of the algorithm SAW, namely:

a. determine the criteria and values

b. perform data normalization

c. preference weights, and

d. perengkingan alternative determination.

This can be seen in the description below.

In the process of determining penilaan teacher performance on SMP Negeri 2 One Roof STM Hillir assessed based on the criteria that have been determined using the SAW to set up a variable that will be used to conduct the performance appraisal process, then steps should be taken to determine the value of the alternative beforehand as follows this:

Table 1

Criteria

\begin{tabular}{ccc}
\hline No. & Criteria & Information \\
\hline 1 & C1 & Pendagogik \\
2 & C2 & Personality \\
3 & C 3 & Social \\
4 & C4 & Professional \\
\hline
\end{tabular}

a. weights Pendagogik

\begin{tabular}{|c|l|c|}
\hline No. & \multicolumn{1}{|c|}{ Description } & Weight \\
\hline 1 & Very good & 4 \\
\hline 2 & Well & 3 \\
\hline 3 & Enough & 2 \\
\hline 4 & moderate & 1 \\
\hline
\end{tabular}

